\title{
Risks of Indoor Overheating in Low-Cost Dwellings on the South African Lowveld
}

\author{
Newton R. Matandirotya, Dirk P. Cilliers, Roelof P. Burger, \\ Christian Pauw, and Stuart J. Piketh
}

\section{Contents}

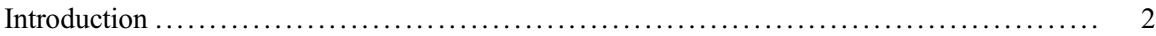

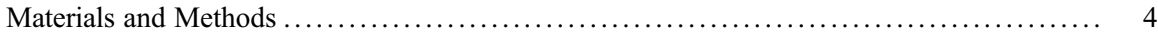

Description of the Study Site and Sampled Dwellings .......................... 4

Description of Indoor Temperature Monitoring Sensors: (Thermochron iButton) ........ 6

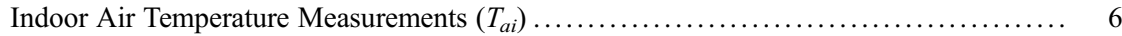

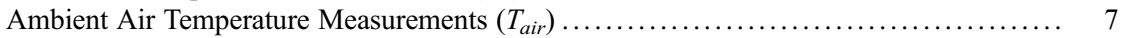

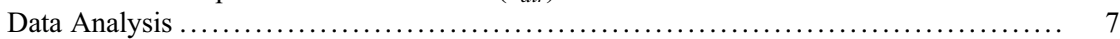

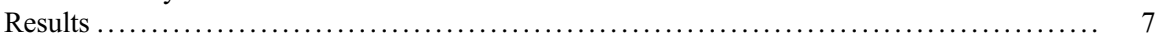

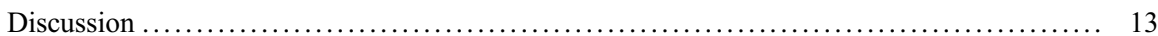

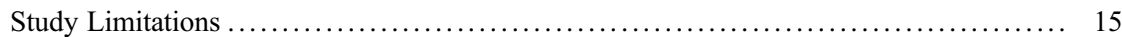

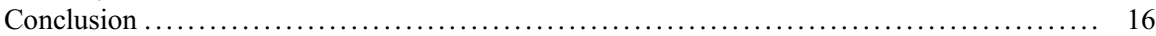

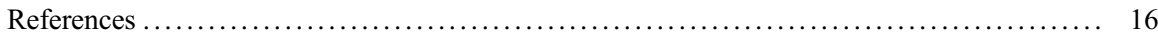

\section{Abstract}

The South African Lowveld is a region of land that lies between 150 and $2000 \mathrm{~m}$ above sea level. In summer the region is characterized by the maximum mean daily ambient temperature of $32^{\circ} \mathrm{C}$. The purpose of the study was to characterize

This chapter was previously published non-open access with exclusive rights reserved by the Publisher. It has been changed retrospectively to open access under a CC BY 4.0 license and the copyright holder is "The Author(s)". For further details, please see the license information at the end of the chapter.

N. R. Matandirotya $(\bowtie) \cdot$ D. P. Cilliers $\cdot$ R. P. Burger $\cdot$ S. J. Piketh Unit for Environmental Sciences and Management, North-West University, Potchefstroom, South Africa e-mail: runyamore@gmail.com; Dirk.Cilliers@nwu.ac.za; roelof.burger@nwu.ac.za; Stuart. Piketh@nwu.ac.za

C. Pauw NOVA Institute, Pretoria, South Africa e-mail: christiaan.pauw@nova.org.za 
indoor thermal environments in low-cost residential dwellings during summer seasons as climate is changing. Indoor and ambient air temperature measurements were performed at a 30-min temporal resolution using Thermochron $i$ Buttons in the settlement of Agincourt. 58 free running low-cost residential dwellings were sampled over the summer seasons of 2016 and 2017. Complementary ambient air temperature data were sourced from the South African Weather Service (SAWS). Data were transformed into hourly means for further analysis. It was found that hourly maximum mean indoor temperatures ranged between $27^{\circ} \mathrm{C}$ (daytime) and $23{ }^{\circ} \mathrm{C}$ (nighttime) for both living rooms and bedrooms in summer 2016 while in 2017 , maximum mean indoor temperatures ranged between $29^{\circ} \mathrm{C}$ (daytime) and $26^{\circ} \mathrm{C}$ (nighttime) in living rooms and bedrooms. Pearson correlations showed a positive association between indoor and ambient temperatures ranging between $r=0.40$ (daytime) and $r=0.90$ (nighttime). The association is weak to moderate during daytime because occupants apply other ventilation practices that reduce the relationship between indoor and ambient temperatures. The close association between nighttime ambient and indoor temperature can also be attributed to the effect of urban heat island as nighttime ambient temperature remain elevated; thus, influencing indoor temperatures also remain high. These findings highlight the potential threat posed by a rise in temperatures for low-cost residential dwellings occupants due to climate change. Furthermore, the high level of sensitiveness of dwellings to ambient temperature changes also indicates housing envelopes that have poor thermal resistance to withstand the Lowveld region's harsh extreme heat conditions, especially during summer. The study findings suggest that a potential risk of indoor overheating exists in low-cost dwellings on the South African Lowveld as the frequency and intensity of heat waves rise. There is therefore a need to develop immediate housing adaptation interventions that mitigate against the projected ambient temperature rise for example through thermal insulation retrofits on the existing housing stock and passive housing designs for new housing stock.

\section{Keywords}

Low-cost dwellings $\cdot$ Indoor temperatures $\cdot$ Climate change $\cdot$ Indoor human thermal comfort · Thermal discomfort · Residential dwellings · Extreme weather · Adaptation $\cdot$ Overheating

\section{Introduction}

Climate change has triggered a rise in external summer air temperature posing a threat to human indoor thermal comfort and health (Mavrogianni et al. 2010) with cities facing a heightened risk of extreme heat from climate change (Araos et al. 2016). On a regional scale temperature rise in sub-Saharan Africa is expected to be higher than global mean temperatures (Webber et al. 2018; Hoegh-Guldberg et al. 2018) as Southern Africa is expected to rise at $2{ }^{\circ} \mathrm{C}$ compared to a global mean of $1.5^{\circ} \mathrm{C}$ (Hoegh-Guldberg et al. 2018). Incidences of extreme weather events around 
the world are increasing as a consequence of climate change with projections showing an increase in the number of warm days/nights putting low-icome earners at risk of physical health threats (Hoegh-Guldberg et al. 2018). The most severe effects of global warming will be reflected through an increase in the frequency and intensity of extreme events such as heatwaves (IPCC 2007; White-Newsome et al. 2012; Dosio 2016). Low-income earners who live in substandard housing are likely to feel the full wrath of temperature rises as they cannot adapt quickly to climatic change.

According to the Chartered Institution of Building Services Engineers (CIBSE Guide A), sleep impairment can be experienced at temperatures above $24{ }^{\circ} \mathrm{C}$ (Mavrogianni et al. 2010). Low-cost residential dwellings that have poor thermal insulation can overheat if exposed to extreme heat. High indoor temperatures also drive energy consumption via the occupants' demand for cooling (Kavgic et al. 2012). Low-cost residential dwellings in South Africa are poorly insulated exposing them to extreme heat effects (Chersich et al. 2018). During hot spellslow-cost structures may be $4-5{ }^{\circ} \mathrm{C}$ warmer than outdoor temperatures (Chersich et al. 2018). Indoor overheating is a function of dwelling thermal insulation levels as well as ventilation practices of occupants (Mavrogianni et al. 2010). Overheating occurs when the indoor operative temperature is over $3{ }^{\circ} \mathrm{C}$ the thermal comfort temperature (Mavrogianni et al. 2010) which the WHO pegged at $24{ }^{\circ} \mathrm{C}$ for indoor environments.

Similar studies on summer indoor temperature monitoring include studies by Summerfield et al. (2007) which monitored 29 dwellings in the United Kingdom (UK) during the summer of 2005-2006 and estimated mean indoor temperatures for living rooms to be $19.8{ }^{\circ} \mathrm{C}$ and $19.3{ }^{\circ} \mathrm{C}$ for bedrooms while Firth and Wright (2008) monitored 224 dwellings in the UK estimating mean living room temperatures at $21.4{ }^{\circ} \mathrm{C}$ and bedroom temperature at $21.5^{\circ} \mathrm{C}$. On the other hand, Mavrogianni et al. (2010) monitored 36 dwellings in London during the summer of 2009. Daytime means in living rooms rose above $28{ }^{\circ} \mathrm{C}$ in three dwellings out of the total 36 sampled while average indoor temperatures in $53 \%$ of living rooms were above indoor thermal comfort temperatures of $25^{\circ} \mathrm{C}$.

The human thermoregulatory mechanism endeavors to maintain a constant core temperature for the body, which commonly requires that the internal heat generated by metabolism be transferred through the skin and lungs to the surrounding environment (Robinson 2000) with the human body temperature being normally maintained at approximately $37{ }^{\circ} \mathrm{C}$ by the anterior hypothalamus through thermoregulation (Hifumi et al. 2018). Heat-related illness develops when the pathological effects of heat load cannot be eliminated from the human body (Szekely et al. 2015) manifesting through excessive loss of water which can induce dehydration and salt depletion (Hifumi et al. 2018). In the event of exposure to extreme high indoor temperatures, removal of excess waste from the body is impeded triggering the core temperature to rise and physical health problems can begin (Robinson 2000). Healthy humans have sufficient heat regulatory which cope with increases in temperature up to a particular threshold; however, beyond a certain point the thermoregulatory system can collapse (Kovats and Hajat 2008). 
Climate change has the potential to result in more heat-related illnesses as the mean global temperatures rise (White-Newsome et al. 2012). Occupants with preexisting diseases, children, and the elderly face the greatest risk from extreme indoor heat (Wright et al. 2017). The WHO estimates the global burden of disease from climate change risk factors to have caused 160,000 premature deaths particularly from heatwaves and floods (Myers et al. 2011). The chronically ill, elderly, and children spend considerable time inside dwellings thus making them more vulnerable to indoor heat exposure (Smargiassi et al. 2008; White-Newsome et al. 2012). Past studies show that Southern Africa is expected to be a climate change hotspot (Hoegh-Guldberg et al. 2018). Most experimental indoor temperature monitoring studies have been done in the Global North hence the study sort to fill this knowledge gap on the threat of climate change on indoor thermal environments in Africa. Adaptation techniques are needed immediately for the housing sector to deal with the impacts of extreme heat on indoor environments (Kinnane et al. 2016). The purpose of the study was to characterize summer indoor thermal environments in low-cost housing units on the South African Lowveld. The chapter is structured as follows: Section "Materials and Methods" describes the materials and methods, Section "Results" presents results, Section "Discussion" presents a discussion of the study, while Section "Conclusion" presents conclusion and plans for future work.

\section{Materials and Methods}

This section outlines the materials and methods used during the study. A brief description of the study site is given followed by a highlight of the indoor sensors used to gather indoor and ambient data.

\section{Description of the Study Site and Sampled Dwellings}

Agincourt/Matsavana (24.8279S: $31.2197 \mathrm{E})$ is a low-income residential settlement on the Lowveld valley and is located in the town of Bushbuckridge Local Municipality in Mpumalanga Province (Wittenberg and Collinson 2017). All sampled dwellings in the study were of a detached nature and were constructed as standalone structures. Dwellings selected were constructed from either hollow block or clay standard bricks or standard cement and sand bricks with no wall plastering and no ceilings and were free running without any mechanical indoor temperature mechanisms but rather depend on occupant ventilation behaviors. Figure 1 represents the study site.

Figure 1 shows the settlement of Agincourt located in the Bushbuckridge Local Municipality in the Lowveld region of South Africa. 


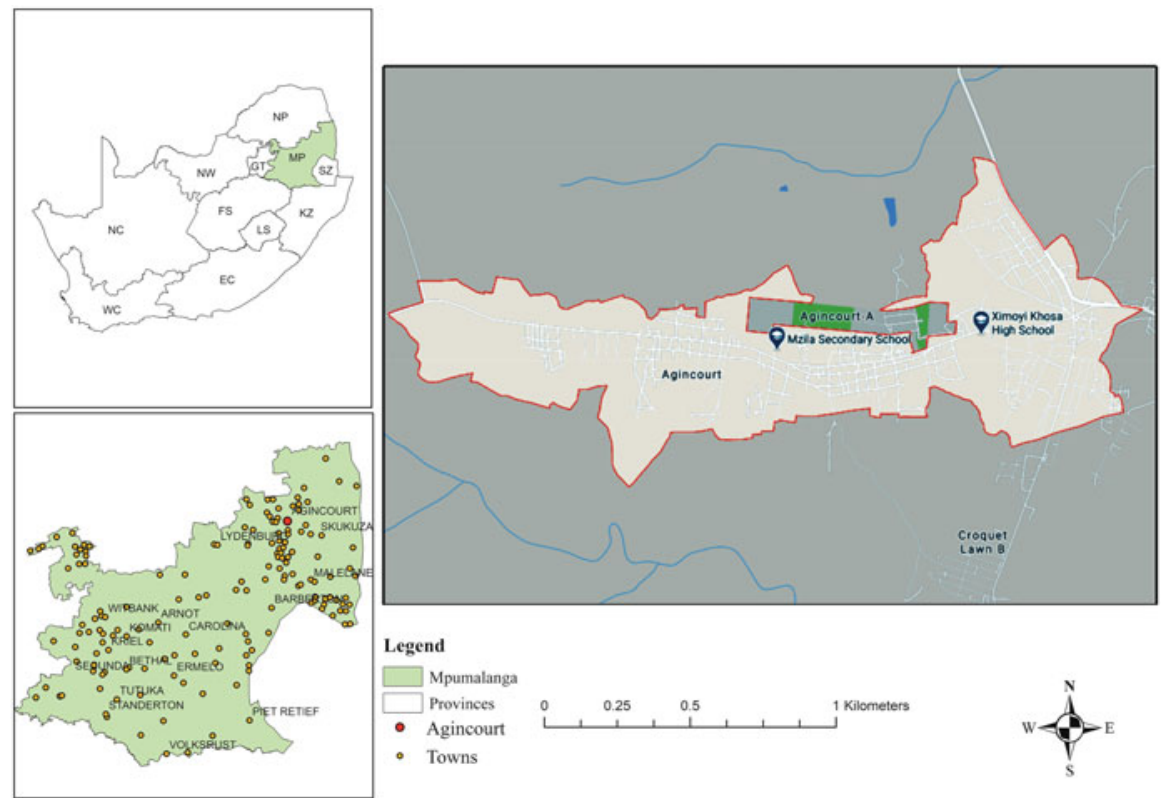

Fig. 1 Agincourt, Mpumalanga Province, South Africa
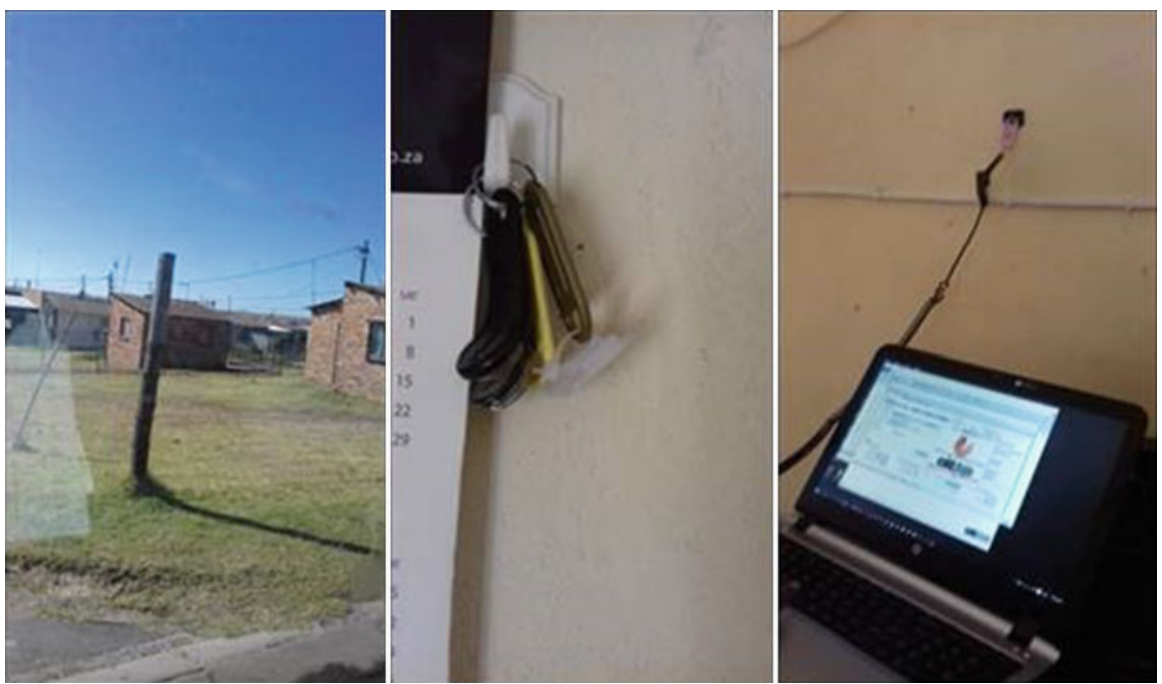

Fig. 2 Low-cost housing units sampled for the study

Figure 2 shows images of sampled dwellings for the study. The majority of dwellings were detached, roofed from iron corrugated iron sheets, none plastered with no ceilings. The left image represents low-cost dwellings, the middle image 
shows iButtons hanged inside a dwelling wall, and the right image shows the data downloading process.

\section{Description of Indoor Temperature Monitoring Sensors: (Thermochron iButton)}

Indoor air temperatures were measured using Thermochron iButton (DS1922L) manufactured by Maxim Integrated Products formerly Dalls Semiconductor (USA) as shown in Fig. 3. Thermochron iButton has a diameter of $17.35 \mathrm{~mm}$ and a thickness of $6 \mathrm{~mm}$ (Johnson et al. 2005). These sensors can measure air temperature range of $-40{ }^{\circ} \mathrm{C}$ to $85{ }^{\circ} \mathrm{C}$. Thermochron loggers are rugged, water-resistant, and self-sufficient sensors that measure temperature and record the result in a protected memory section (Hubbart et al. 2005). Figure 3 shows the image of a Thermochron $i$ Button used in the study.

\section{Indoor Air Temperature Measurements $\left(T_{a i}\right)$}

In each dwelling, two occupied spaces were identified: living rooms and bedrooms with a single sensor (Thermochron iButton) being installed in each room. Living rooms were chosen as this is the space where occupants spend considerable time during the daytime while the bedroom is mostly occupied at night. Air temperature in living rooms space was used as a proxy indicator or for occupant daytime exposure to extreme temperature while the bedroom air temperature was used as a proxy indicator for nighttime extreme indoor temperature exposure. Indoor sensors

Fig. 3 Thermochron $i$ Button used for indoor and ambient temperature measurement

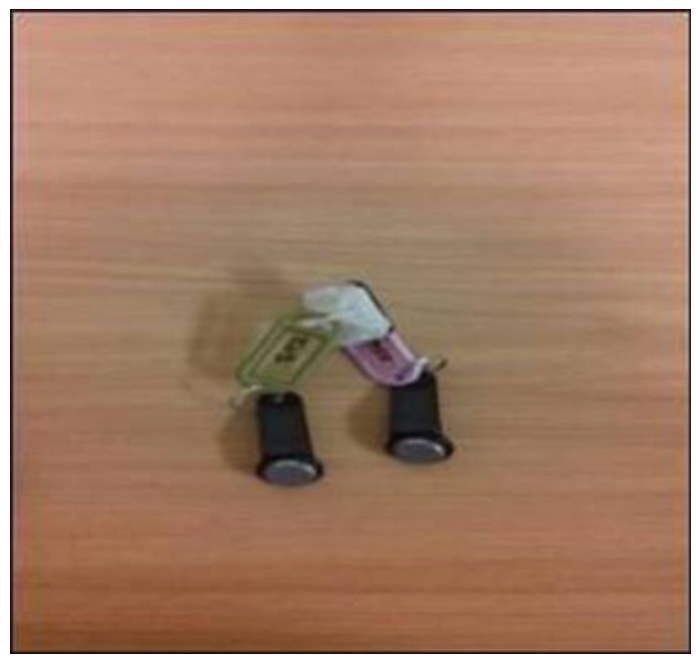


were placed at a standard height of $1.5 \mathrm{~m}-1.6 \mathrm{~m}$ above ground as applied in Healy and Clinch (2002), Yohanis and Mondol (2010), Newsome et al. (2012), Kane (2013), Lee and Lee (2015) and Magalhaes et al. (2016). Precautions were taken to make sure that sensors were not obstructed by furniture away from direct sunlight, heat, or any form of heat radiation (Malama and Sharpless 1996; Mavrogianni et al. 2010; Loughnan et al. 2015; Lee and Lee 2015; San Miguel-Bellod et al. 2018). Measurements were done continuously over a $24-\mathrm{h}$ cycle at a 30-min temporal resolution.

\section{Ambient Air Temperature Measurements ( $\left.T_{\text {air }}\right)$}

Ambient air temperature measurements were done using the same sensors as indoor temperatures (Thermochron $i$ Button DS1922L). Similar to indoor measurements loggers were set to collect data at a 30-min temporal resolution over a 24-h cycle. Before deployment, all sensors were calibrated and tested for accuracy in the laboratory by the manufacturer (Matandirotya et al. 2019). Supplementary ambient air temperature data were obtained from the South African Weather Service (SAWS) nearest weather station.

Table 1 shows the number of summer indoor monitoring days during the 2016 and 2017 surveys. In 2016 indoor monitoring was done for a total of 17 days while for 2017 monitoring was done for 37 days.

\section{Data Analysis}

The study defined daytime as 8:00 am to 8:00 pm while nighttime was staggered from $9.00 \mathrm{pm}$ to $7 \mathrm{am}$. For each room, hourly mean temperatures were calculated for the whole monitoring period. To establish the association/relationship between indoor and ambient temperatures at different times of day, indoor and ambient temperature were correlated using simple linear regression. Pearson values were used as a proxy indicator of insulation material strength. Section "Results" presents the results of the study.

\section{Results}

This section presents the results of the study. Tables 2 and 3 highlight the descriptive of indoor and ambient temperatures during the indoor monitoring campaigns.

Table 1 Indoor temperature monitoring times

\begin{tabular}{l|l|l|l}
\hline Study site & From & To & Number of monitoring days \\
\hline Agincourt 2016 & 13 April 2016 & 30 April 2016 & 17 \\
\hline Agincourt 2017 & 1 February 2017 & 9 March 2017 & 37 \\
\hline
\end{tabular}


Table 2 Descriptive statistics for summer 2016

\begin{tabular}{l|l|l|l|l}
\hline & $\begin{array}{l}\text { Minimum } \\
\left({ }^{\circ} \mathrm{C}\right)\end{array}$ & $\begin{array}{l}\text { Maximum } \\
\left({ }^{\circ} \mathrm{C}\right)\end{array}$ & $\begin{array}{l}\text { Mean } \\
\left({ }^{\circ} \mathrm{C}\right)\end{array}$ & $\begin{array}{l}\text { Std. } \\
\text { Deviation }\end{array}$ \\
\hline Ambient daytime & 17 & 38 & 27 & 5 \\
\hline Living room daytime $(n=31)$ & 21 & 33 & 27 & 3 \\
\hline Bedroom daytime $(n=19)$ & 20 & 34 & 27 & 2 \\
\hline Ambient nighttime & 16 & 26 & 21 & 2 \\
\hline $\begin{array}{l}\text { Living room nighttime } \\
(n=31)\end{array}$ & 20 & 29 & 24 & 2 \\
\hline Bedroom nighttime $(n=19)$ & 18 & 28 & 23 & 2
\end{tabular}

Table 3 Descriptive statistics for summer 2017

\begin{tabular}{l|l|l|l|l}
\hline & $\begin{array}{l}\text { Minimum } \\
\left({ }^{\circ} \mathrm{C}\right)\end{array}$ & $\begin{array}{l}\text { Maximum } \\
\left({ }^{\circ} \mathrm{C}\right)\end{array}$ & $\begin{array}{l}\text { Mean } \\
\left({ }^{\circ} \mathrm{C}\right)\end{array}$ & $\begin{array}{l}\text { Std. } \\
\text { Deviation }\end{array}$ \\
\hline Ambient daytime & 19 & 41 & 29 & 7 \\
\hline Living room daytime $(n=27)$ & 21 & 36 & 29 & 4 \\
\hline Bedroom daytime $(n=27)$ & 21 & 37 & 29 & 4 \\
\hline Ambient nighttime & 18 & 28 & 22 & 2 \\
\hline $\begin{array}{l}\text { Living room nighttime } \\
(n=27)\end{array}$ & 21 & 33 & 26 & 3 \\
\hline Bedroom nighttime $(n=27)$ & 21 & 33 & 26 & 3 \\
\hline
\end{tabular}

Table 2 represents descriptive statistics of indoor and ambient temperatures during the summer of 2016. The daytime ambient mean was higher than the nighttime mean by $6{ }^{\circ} \mathrm{C}$. The trend was also observed for indoor temperatures during day and nighttime. The occupied spaces bedrooms and living rooms had similar means during daytime at $27^{\circ} \mathrm{C}$, while at nighttime there is $0.6^{\circ} \mathrm{C}$ difference between living rooms and bedrooms with living rooms being slightly warmer. Living rooms are occupied spaces during daytimes so there was a potential of thermal discomfort as a result of temperatures exceeding the WHO maximum indoor temperature guideline of $24{ }^{\circ} \mathrm{C}$. During the nighttime, there was also a marginal chance of thermal discomfort as the bedroom temperatures were close to breaching the $24{ }^{\circ} \mathrm{C}$ mark.

Table 3 represents descriptive statistics of indoor and ambient temperatures during summer 2017. A similar trend to 2016 was observed as mean daytime ambient temperatures were higher than nighttime temperatures by a $7.4{ }^{\circ} \mathrm{C}$. Occupied spaces (living rooms and bedrooms) showed similar daytime and nighttime behaviors. Daytime differences between bedrooms and living rooms were by $0.2^{\circ} \mathrm{C}$, while at nighttime the difference was by $0.4{ }^{\circ} \mathrm{C}$. There were very marginal differences between the rooms sampled. Figure 4 represents the density distribution of indoor temperatures in bedrooms during the summer of 2016.

Figure 4 represents indoor temperature density distribution in bedrooms during the summer of 2016. Throughout the summer monitoring period, all bedrooms had median temperatures above $24{ }^{\circ} \mathrm{C}$ beyond the WHO maximum temperature 

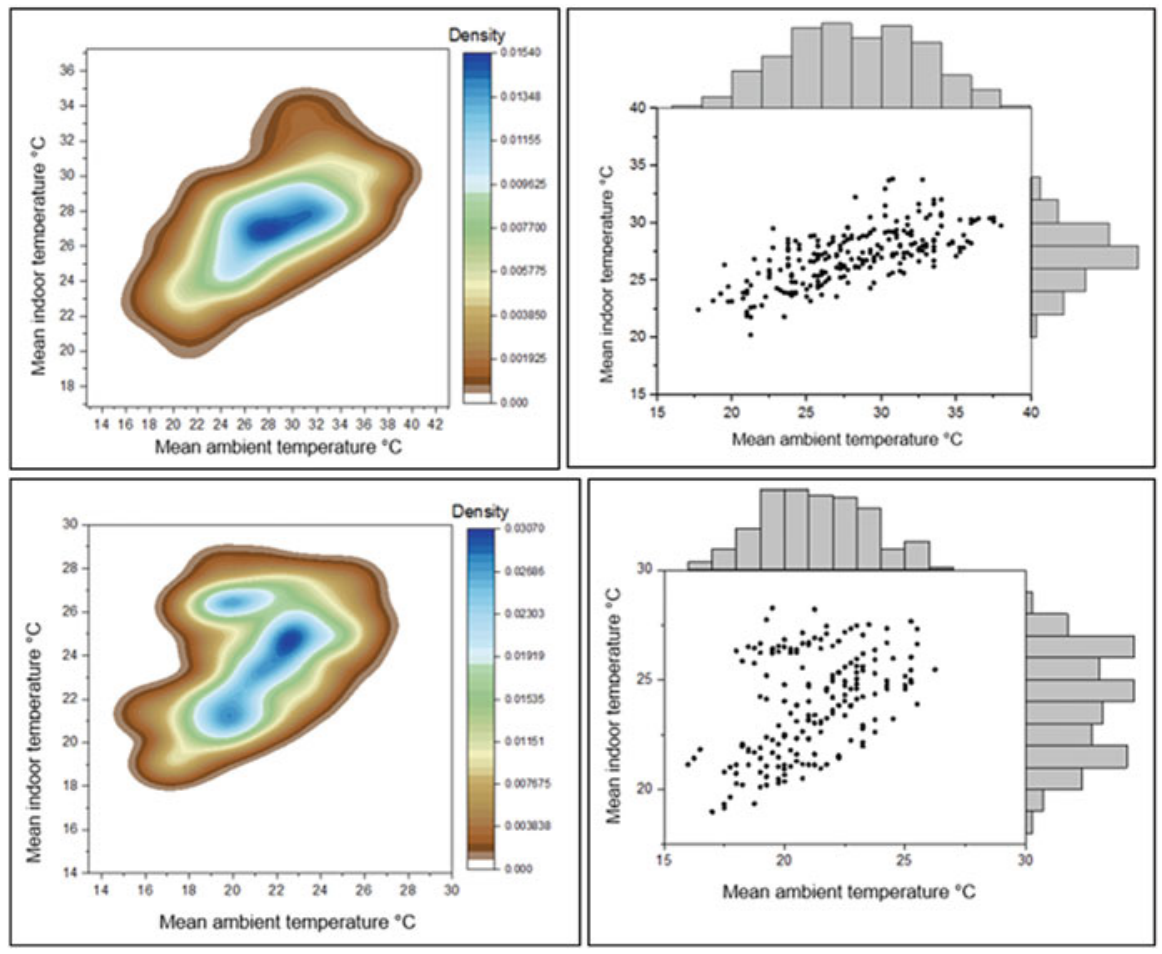

Fig. 4 Density distribution and marginal histograms of indoor temperatures in bedrooms during the summer of 2016. Top-row represents daytimes while the bottom row represents nighttimes

guideline for thermal discomfort. High bedroom temperature beyond the prescribed $24{ }^{\circ} \mathrm{C}$ has the potential to cause sleep impairment especially at night when space is used for night resting. Besides causing sleep impairment high indoor temperatures can cause excessive sweating that ultimately can cause dehydration as well as heat exhaustion. Figure 5 shows the density indoor temperature distribution for bedrooms during the summer of 2017.

Figure 5 shows indoor temperature density in bedrooms during the summer of 2017. During daytimes, indoor temperatures were in the region above $25^{\circ} \mathrm{C}$ with minimum hourly mean temperatures being above $20^{\circ} \mathrm{C}$ in all bedrooms sampled. The study assumed that this space is not occupied during the daytime; therefore, no risk was anticipated to occupants. According to Fig. 4, temperatures remained high at nighttime with minimum mean nighttime temperature remaining above $20^{\circ} \mathrm{C}$. The high indoor temperatures are mainly from solar radiation absorption which happens during the day which spills over into nightime since occupants do not have mechanisms to artificially regulate their indoor environments. The impact of these high nighttime indoor temperatures is that occupants are likely to suffer sleep impairment with a potential to loose fluids. With these high ambient temperatures, there is a likelihood of indoor overheating during both daytime and nighttimes. 

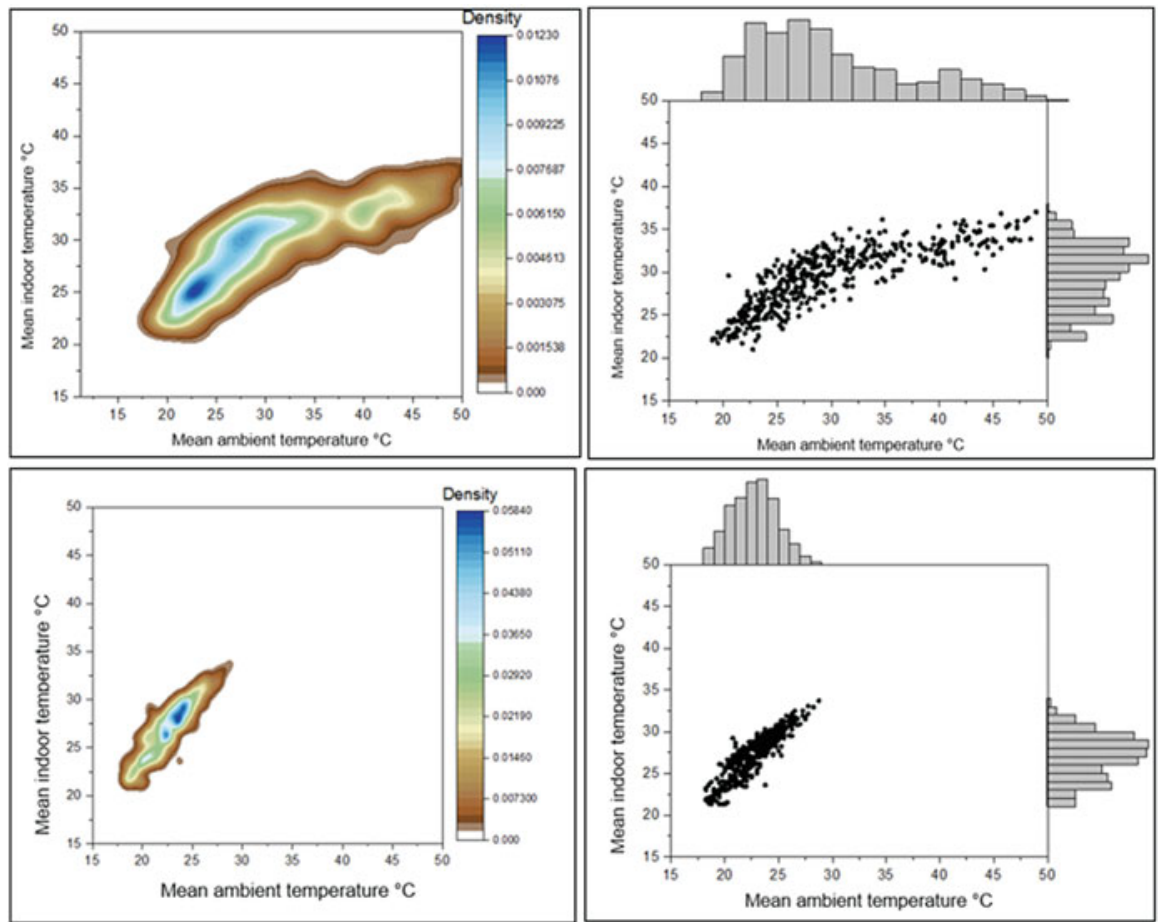

Fig. 5 Density distribution and marginal histograms of indoor temperatures in bedrooms during the summer of 2017. Top-row represents daytime while the bottom row represents nighttime

Figure 6 shows indoor temperature density distribution in living rooms during the summer of 2016.

Figure 6 shows the density distribution and marginal histograms of indoor temperatures in living rooms during the summer of 2016. The study assumed that living rooms are occupied in space during the daytime. The highest concentration was recorded at mean indoor temperatures of $26^{\circ} \mathrm{C}$ during the day, while at night the highest concentration was at $24{ }^{\circ} \mathrm{C}$. The biggest threat to human indoor thermal comfort came from daytime occupation of living rooms as temperatures were at the most time above $24{ }^{\circ} \mathrm{C}$ the prescribed thermal comfort temperatures by the WHO. The impact on occupants is that they are likely to lose a lot of bodily fluids from this exposure to high temperatures.

This trend was similar to that observed in bedrooms over the same summer monitoring period. A threat to human thermal comfort can only be experienced in this space during the day as people are expected to be occupying this space while on the other hand if the temperatures breach the $24{ }^{\circ} \mathrm{C}$ threshold at night it is a threat to those households that use living space for sleeping purposes thus sleep impairment can happen. Concerning thermal insulation material, the high indoor temperatures 

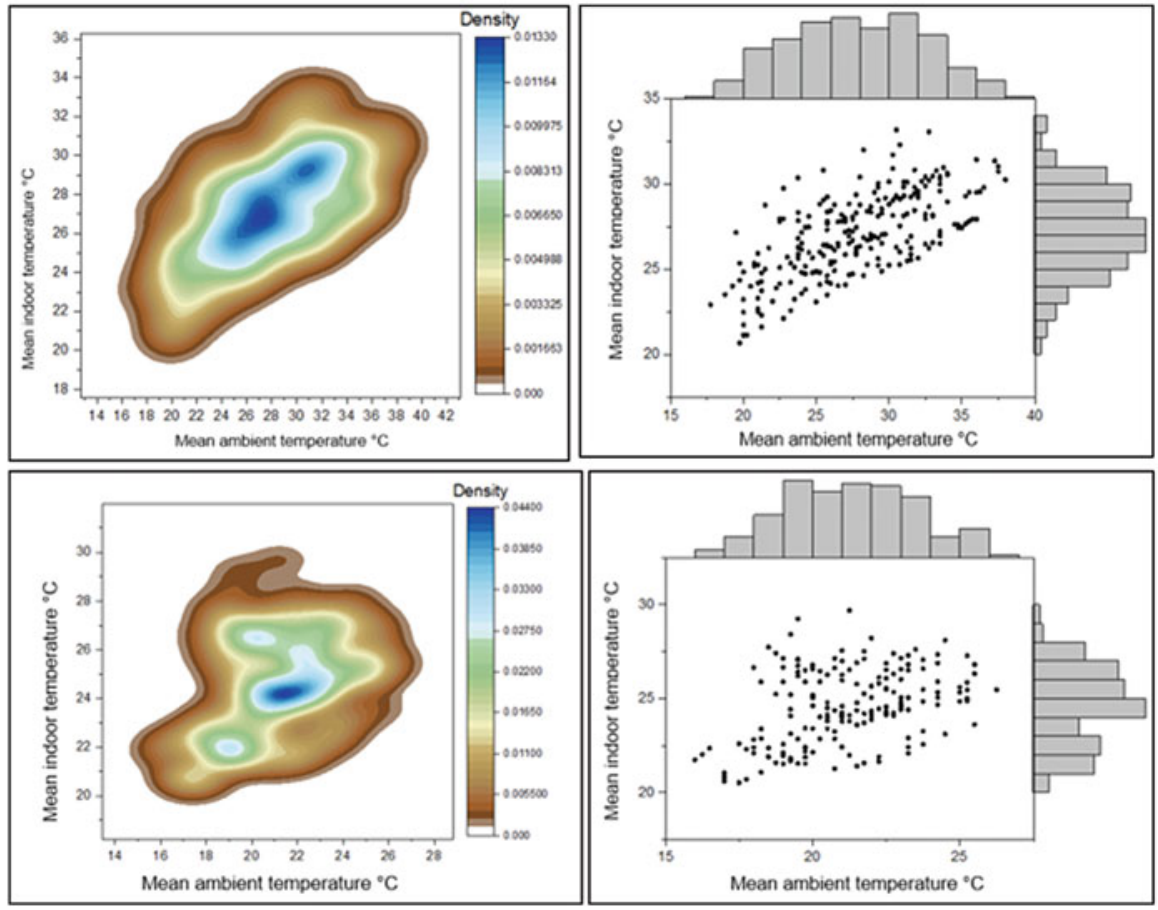

Fig. 6 Density distribution and marginal histograms of indoor temperatures in living rooms during the summer of 2016. Top row represents daytime while the bottom row represents nighttime

indicate that the thermal material is of poor thermal capacity. Figure 7 shows indoor temperature density distribution in living rooms during the summer of 2017.

Figure 7 shows the density distribution of indoor temperatures during the day and nighttimes. A similar trend was observed as in the summer of 2016 where the daytime minimum mean temperatures were recorded at above $20{ }^{\circ} \mathrm{C}$ while at nighttime they remained high with the minimum mean recorded in living rooms being at $21^{\circ} \mathrm{C}$. The impact on occupants was expected during the daytime as the study expected occupants to be occupying this space. Negative thermal effects are expected in living rooms if the indoor temperatures are above $24{ }^{\circ} \mathrm{C}$ during the day as people are expected to be occupying this space while it can have negative thermal impacts if occupants use this space for sleeping purposes during the night. The high indoor temperatures show that the thermal material used is weak in comparison to the high ambient temperatures experienced in the region thereby exposing occupants to extremely high indoor temperatures. It, therefore, implies that dwellings need to be constructed from a thermal material with the appropriate R-value and resistance capability to withstand the high levels of solar radiation. Measuring R-values of the building material was beyond the scope of this thesis but can be a future line of research. Figure 8 shows simple linear regression results for mean indoor and ambient temperatures in bedrooms during the summers of 2016 and 2017. 

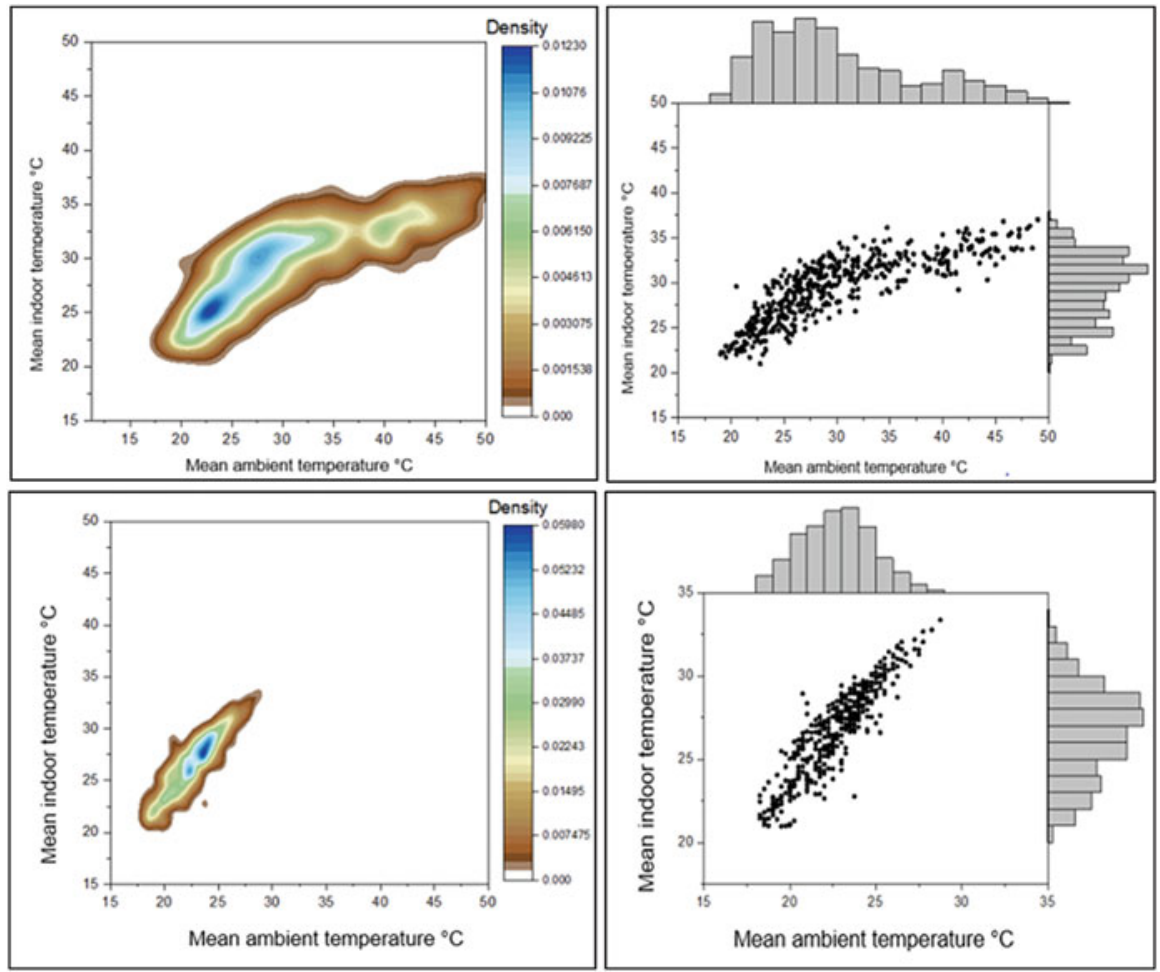

Fig. 7 Density distribution of indoor temperatures and marginal histograms in living rooms over the summer 2017 monitoring period. Top-row represents daytimes while the bottom row represents nighttimes

Figure 8 shows the simple linear regression results in bedrooms during the 2016 and 2017 indoor monitoring surveys. During both surveys, ambient temperatures were a good predictor of indoor temperatures with the strongest association being observed during the nighttime of 2017 monitoring $(\mathrm{r}=0.90)$, while the least association was observed during nighttime of $2016(\mathrm{r}=0.47)$. The strong relationship between ambient air temperatures and indoor temperatures shows the weakness in the thermal fabric of the material used to construct the sampled dwellings. Figure 9 shows simple linear regression results for mean indoor and ambient temperatures in living rooms during the summers of 2016 and 2017.

Figure 9 shows simple linear regression results of mean indoor and ambient temperatures in living rooms. The strongest association was observed during the night of 2017 monitoring $(\mathrm{r}=0.90)$ while the least association was observed during nighttimes of 2016 at $r=0.40$. The strong relationship indicates that these low-cost dwellings are highly sensitive to ambient temperature changes. 

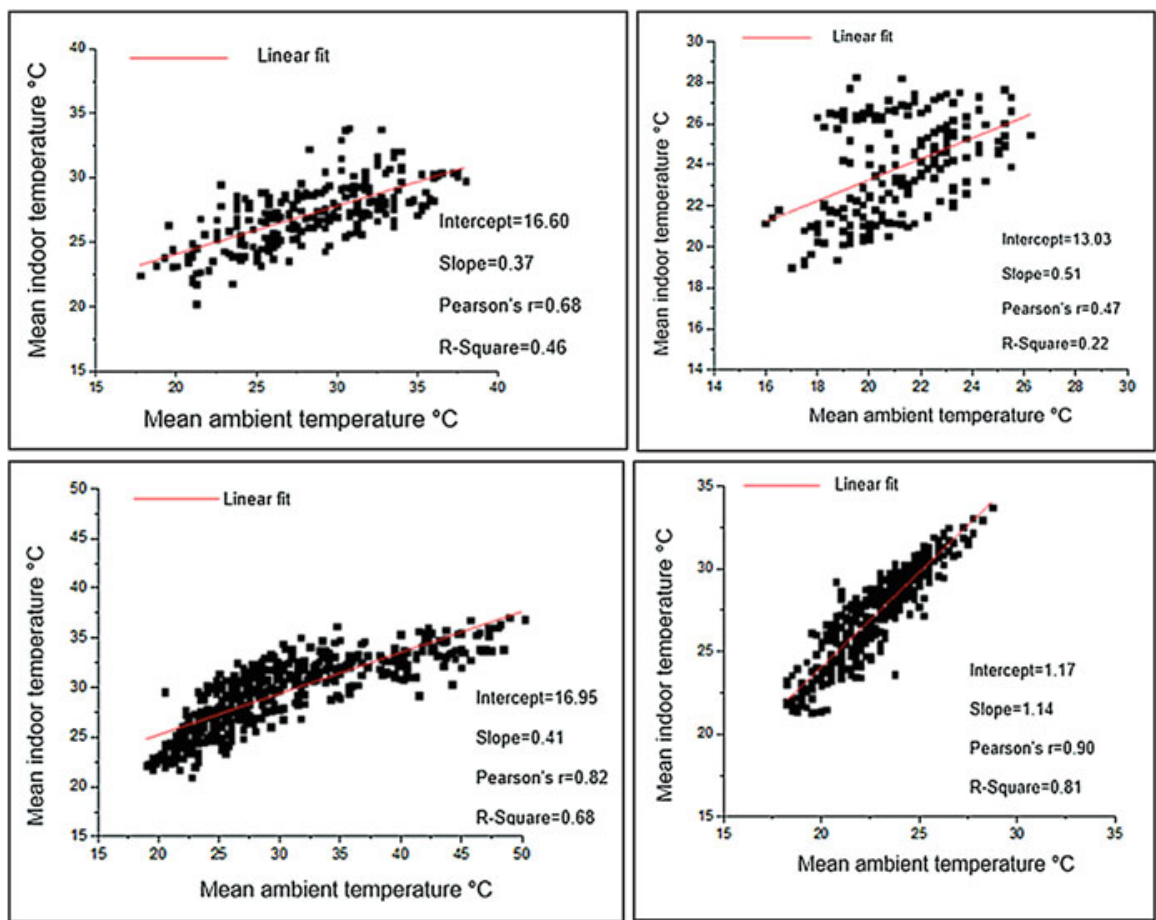

Fig. 8 Regression results for mean indoor and ambient temperatures in bedrooms. Top-row represents bedrooms 2016, while the bottom row represents 2017. The left image represents daytime while right image represents nighttime

\section{Discussion}

During summer 2016, the study observed that $100 \%$ of bedrooms had mean daytime temperatures above $24{ }^{\circ} \mathrm{C}$ through the monitoring period, while $53 \%$ of the same bedrooms recorded night temperatures exceeding $24{ }^{\circ} \mathrm{C}$. In 2017 , during both daytime and nighttime, $100 \%$ of bedrooms had daytime mean temperatures above $24{ }^{\circ} \mathrm{C}$. The implication of being exposed to such indoor temperatures for a long time is that occupants lose a lot of fluids that can lead to dehydration. At night sleep impairment can also be experienced due to the high indoor temperatures. The population likely to be negatively affected most are young children and the elderly. Young children suffer from high heat exposure because their thermoregulatory system will not have developed much while for the elderly the thermoregulation system starts to suffer from dysfunction as sweating glands get blocked with aging hence not much sweat is generated to cool off the body. In both instances, it results in heat build-up within the body thereby putting a strain on the core. A strained core can end with such heat-related negative illnesses such as heat strokes, heat cramps, or heat exhaustion (Myers et al. 2011). 

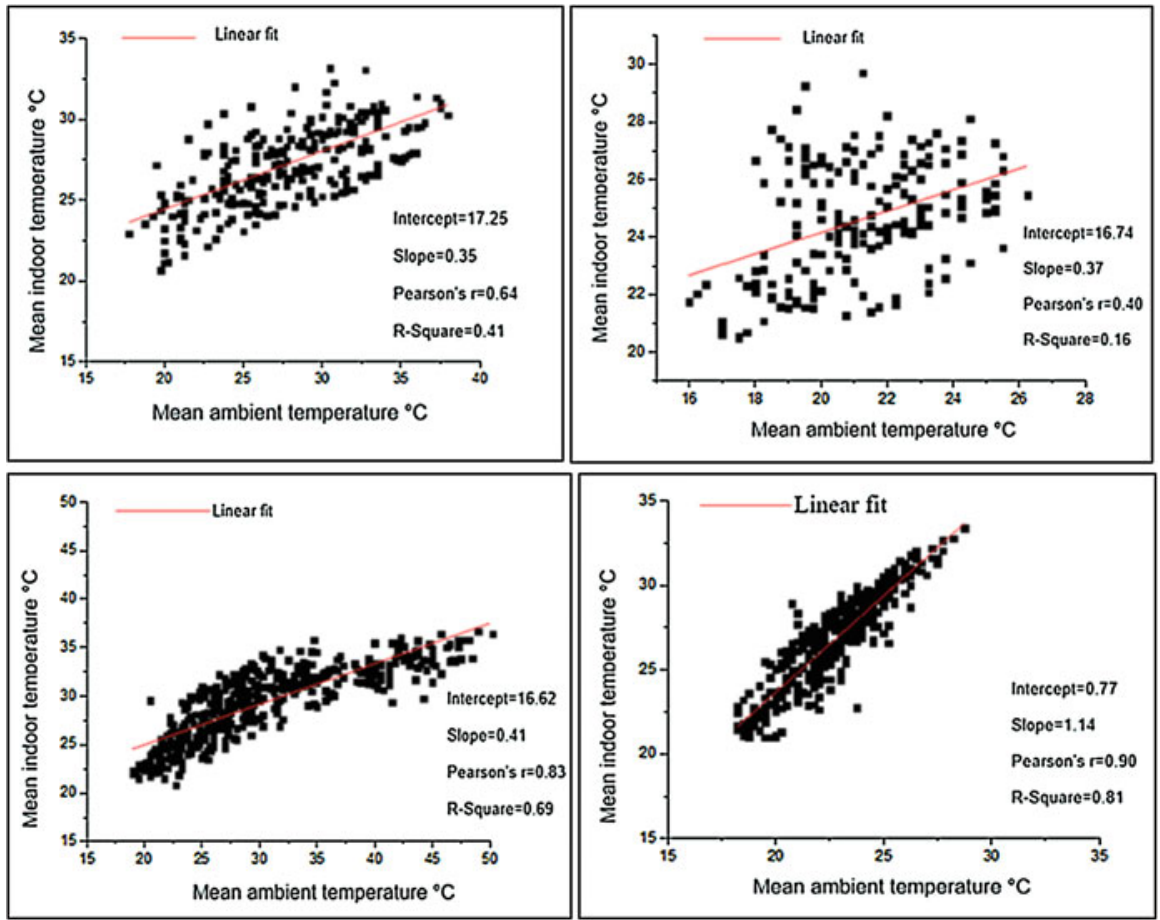

Fig. 9 Regression results of mean indoor and ambient temperatures in living rooms. The top row represents living rooms during 2016 while the bottom row represents living rooms 2017 . The left image represents daytime, while right image represents nighttime during summer 2017

A similar trend to bedroom indoor temperature variations was observed in living rooms wherein $100 \%$ of living rooms in 2016 breached the $24{ }^{\circ} \mathrm{C}$ threshold, while at night $87 \%$ of sampled dwellings had mean temperatures above $24{ }^{\circ} \mathrm{C}$. In 2017 , the study observed that $100 \%$ of living rooms had mean daytime and nighttime indoor temperatures above $24{ }^{\circ} \mathrm{C}$ providing ideal conditions for indoor overheating. The high indoor temperatures recorded by the study during 2017 can be attributed to the monitoring period wherein temperature monitoring was done during the peak of summer season in February unlike the 2016 survey where temperature monitoring was done in April which is towards the period of transition to winter on the South African Lowveld. For living rooms, the study anticipated the greatest threat to indoor thermal comfort during daytime as people are occupying this space unlike at night where occupants shift to bedrooms. Prolonged exposure to high indoor temperatures can have devastating effects on those occupants already having underlying health conditions which can worsen.

The study also established that the sampled structures were highly sensitive to ambient temperature changes as confirmed by the strong positive Pearson correlations between indoor and ambient temperatures. The sensitiveness was observed for both day and nighttimes. This confirms that the thermal fabric of sampled dwellings 
is weak with an inability to regulate indoor temperatures as desired. If the thermal insulation is fully functional, it could act as a barrier to incoming solar radiation during the day and also be complemented by various ventilation practices put in place by occupants. Since the dwellings sampled were free running, occupants had no opportunity to artificially regulate indoor thermal environments. An increase in heat weather events in South Africa is likely to increase exposure to elevated temperatures for the poor which can be classified as a climate-related health threat (Wright et al. 2017). With ambient temperatures expected to continue on an upward trajectory as a result of climate change, there is a need to improve the thermal fabric of low-cost dwellings which can be achieved through thermal insulation retrofits for existing housing stock while for a new housing stock passive designs can be integrated. These two adaptation strategies can be of help to regulate indoor thermal conditions. The study findings concur to studies by Makaka and Meyer (2005), Naicker et al. (2017), Matandirotya et al. (2019) which also estimated that low-cost dwellings are sensitive to ambient temperature changes because of poor insulation. In a study by Mavrogianni et al. (2010), 53\% of livingrooms average indoor temperatures were above thermal comfort levels of $24{ }^{\circ} \mathrm{C}$ while $86 \%$ of recorded temperatures could result in sleep impairment. Residents of low-cost dwellings are therefore at risk of being exposed to indoor thermal discomfort as temperatures continue to rise as a consequence of climate change.

Extreme high indoor temperature as a result of climate change is bringing several challenges for the built environment as people spend considerable time indoors; hence, the effects are likely to belong-lasting if appropriate adaptation interventions are not introduced especially for the poor marginalized populations who already occupy substandard housing. The study, therefore, brings to the fore the current existing indoor thermal environments in low-cost housing in the context of climate change. One of the possible immediate mitigation measures includes thermal insulation retrofits for the existing housing stock while for new housing stock passive designs can be incorporated. These measures improve the ability of housing structures to regulate indoor thermal environments. Furthermore, greening programs, urban planning, and housing are also other strategies that can be used to mitigate against devastating health threats from climate change (Wright et al. 2017). Future work will focus on measuring the thermal resistance capacity of building materials used for the construction of low-cost dwellings on the South Africa Lowveld region.

\section{Study Limitations}

The study had single sensors deployed in each room during monitoring; therefore, there was no mechanism to account for indoor vertical and horizontal temperature gradients. To mitigate this limitation, the study had to position sensors at the center of rooms where possible without interfering with occupants' daily activities. The study also could not take into account other indoor sources of radiant heat or ventilation practices that could impact on indoor temperatures. Additionally, the other limitation was that the study could not measure humidity which could 
facilitated the calculation of apparent temperatures which is an indicator of thermal sensation. Future studies will take into account these factors.

\section{Conclusion}

The study estimated that there is a risk of indoor overheating in low-cost dwellings on the South African Lowveld as a consequence of poorly insulated dwellings and a rise in temperatures from climate change. Occupants were exposed to indoor temperatures which breached the $\mathrm{WHO}$ maximum thermal guideline of $24^{\circ} \mathrm{C}$ subjecting occupants to various physical health threats in the event of prolonged exposure. It is therefore imperative that adaptation and mitigation strategies on the existing housing stock are applied in order to reduce the effects of climate change on occupants. Future work will focus on community participation in the development of housing designs that are climate resilient and suit the changing climatic conditions of Southern Africa.

Acknowledgments Acknowledgments go to Brigitte Language who did data collection for the study working under the Prospective Household Observational cohort study of Influenza, Respiratory Syncytial Virus and other respiratory pathogens community burden and Transmission dynamics in South Africa (The PHIRST Study) supported by a grant from the United States Centre for Disease Control and Prevention and conducted by the National Institute for Communicable Disease of the National Health Laboratory Service. Ethical approval for the PHIRST study was obtained from the University of Witwatersrand, Johannesburg HREC (150808). Acknowledgments are also extended to South Weather Service for the provision of ambient temperature data.

\section{References}

Araos M, Berrang-Ford L, Ford JD, Austin SE, Biesbroek R, Lesnikowski A (2016) Climate change adaptation planning in large cities: a systematic global assessment. Environ Sci Pol 66:375-382. https://doi.org/10.1016/j.envsci.2016.06.009

Chersich MF, Wright CY, Venter F, Rees H, Scorgie F, Erasmus B (2018) Impacts of climate change on health and wellbeing in South Africa. Int J Environ Res Public Health. https://doi.org/ 10.3390/ijerph15091884

Dosio A (2016) Projection of temperature and heat waves for Africa with an ensemble of CORDEX regional climate models. https://doi.org/10.1007/s00382-016-3355-5

Firth SK, Wright AJ (2008) Investigating the thermal characteristics of English dwellings: summer temperatures: proceedings of conference: air conditioning and the low carbon cooling challenge: Cumberland Lodge, Windsor, 27-29 July 2008. Network for Comfort and Energy, London. Available at http://nceub.org.uk. Accessed 20 Jan 2019

Healy JD, Clinch JP (2002) Fuel poverty, thermal comfort and occupancy: results of a national household-survey in Ireland. Applied Energy 73(3-4):329-343. https://doi.org/10.1016/S03062619(02)00115-0

Hifumi T, Kondo Y, Shimuzu K, Miyake Y (2018) Heatstroke. J Intensive Care 6:30. https://doi. org/10.1186/s40560-018-0298-4

Hoegh-Guldberg O, Jacob D, Taylor M, Bindi S, Brown I, Camiloni A, Diedhiou R, Djalante K.L, Ebi F, Engelbrecht J, Guiot Y, Hijioka S, Mehrotra A, Payne S.I, Seneviratne A, Thomas Warren $\mathrm{R}$, Zhou $\mathrm{G}$ (2018) Impacts of $1.5^{\circ} \mathrm{C}$ of global warming on natural and human systems. In: 
Masson-Delmotte V, Zhai P, Portner HO, Roberts D, Skea J, Shukla PR, Pirani A, MoufoumaOkia W, Pean C, Pidcock R, Connors S, Matthews JBR, Chen Y, Zhou X, Gomis MI, Lonnoy E, Maycock T, Tignor M, Waterfields T (eds) Global warming of $1.5^{\circ} \mathrm{C}$. An IPCC Special Report on the impacts of global warming of $1.5^{\circ} \mathrm{C}$ above pre-industrial levels and related global greenhouse gas emission pathways, in the context of strengthening the global response to the threat of climate change, sustainable development, and efforts to eradicate poverty. [In Press]. https://www.ipcc.ch/sr15/chapter/spm/

Hubbart J, Link T, Campbell C, Cobos D (2005) Evaluation of a low-cost temperature measurement system for environmental applications. Hydrol Process 19:1517-1523. https://doi.org/10.1002/ hyp.5861

IPCC (2007) Climate change 2007: the physical science basis: contribution of Working Group 1 to the Fourth Assessment Report of the Intergovernmental Panel on Climate Change. Cambridge University Press, Cambridge, UK/New York. https://wg1.ipcc.ch/publications/wg1-ar4/faq/ docs/AR4WG1_FAQ-Brochure_LoRes.pdf

Johnson AN, Boer BR, Woessner WW, Stanford JA, Poole GC, Thomas SA, O'Daniel SJ (2005) Evaluation of an inexpensive small-diameter temperature logger for documenting ground waterriver interactions. Groundwater Monitoring \& Remediation 25(4):68-74. https://doi.org/ 10.1111/j.1745-6592.2005.00049.x

Kane T (2013) Indoor temperatures in UK dwellings: investigating heating practices using field survey data. Ph.D. thesis, Loughborough University Institutional Repository. https://hdl.handle. net $/ 2134 / 12563$

Kavgic M, Summerfield A, Mumovic D, Stevanovic ZM, Turanjanin V, Stevanovic ZZ (2012) Characteristics of indoor temperatures over winter for Belgrade urban dwellings: indications of thermal comfort and space heating energy demand. Energ Buildings 47:506-514. https://doi. org/10.1016/j.enbuild.2011.12.027

Kinnane O, Grey T, Dyer M (2016) Adaptable housing design for climate change adaptation. Proc Inst Civ Eng Eng Sustain 170(5):249-267. https://doi.org/10.1680/jensu.15.00029

Kovats SR, Hajat S (2008) Heat stress and public health: a critical review. Annu Rev Public Health 29:41-55. https://doi.org/10.1146/annurev.publhealth.29.020907.090843

Lee K, Lee D (2015) The relationship between indoor and outdoor temperature in two types of residence. Energy Procedia 78:2851-2856. 6th international building physics conference, IBPC 2015. https://doi.org/10.1016/j.egypro.2015.11.647

Loughnan M, Carrol M, Tapper NJ (2015) The relationship between housing and heatwave resilience in older people. Int J Biometeorol 59:1291-1298. https://doi.org/10.1007/s00484014-0939-9

Magalhaes SMC, Leal VMC, Horta IM (2016) Predicting and characterizing indoor temperatures in residential buildings. Results from a monitoring campaign in Northern Portugal. Energ Buildings 119:293-308. https://doi.org/10.1016/j.enbuild.2016.03.064

Makaka G, Meyer E (2005) Temperature stability of traditional and low-cost modern housing in the Eastern Cape, South Africa. J Build Phys 30(1). https://doi.org/10.1177/1744259106065674

Malama A, Sharpless S (1996) Thermal performance of traditional and contemporary housing in cool-season of Zambia. Build Environ 32(1):69-78. https://doi.org/10.1016/S0360-1323(96) 00036-4. 1997

Matandirotya NR, Cilliers DP, Burger RP, Language B, Pauw C, Piketh SJ (2019) The potential for domestic thermal insulation retrofits on the South African Highveld. Clean Air J 29(1). https://doi.org/10.17159/2410-972X/2019/v29n1a1

Mavrogianni A, Davie M, Wilkinson P, Pathan A (2010) London housing and climate change: impact on comfort and health-preliminary results of a summer overheating study. Open House Int 35(2):49-59

Miguel-Bellod JS, Gonzalez-Martinez P, Sanchez-Ostiz A (2018) The relationship between poverty and indoor temperatures in winter: determinants of cold homes in social housing contexts from 40s-80s in Northern Spain. Energ Buildings 173:428-442. https://doi.org/10.1016/j. enbuild.2018.05.022 
Myers J, Young T, Galloway M, Manyike P, Tucker T (2011) A public health approach to the impact of climate change on health in Southern Africa-identifying priority modifiable risk. S Afr Med J $=$ Suid-Afrikaanse tydskrif vir geneeskunde 101(11):817-820. https://doi.org/10.7196/ samj.5267

Naicker N, Teare J, Balakrishna Y, Wright CY, Mathee A (2017) Indoor temperatures in low-cost housing in Johannesburg. Int J Environ Res Public Health 14(11). https://doi.org/10.3390/ ijerph 14111410

Robinson PJ (2000) On the definition of a heat wave. J Appl Meteorol 40. https://doi.org/10.1175/ 1520-0450(2001)040<0762:OTDOAH > 2.0.CO;2

Smargiassi A, Fourneir M, Griot C, Baudouin Y, Kosatsky T (2008) Prediction of the indoor temperatures of an urban area with an in-time regression mapping approach. J Expo Sci Environ Epidemiol 18:282-288. https://doi.org/10.1038/sj.jes.7500588

Summerfield AJ, Lowe RJ, Bruhns HR, Caeiro JA, Steadman JP, Oreszcyn T (2007) Milton Keynes Energy Park revisited: changes in internal temperatures and energy usage. Energ Buildings 39:783-791. https://doi.org/10.1016/j.enbuild.2007.02.012

Szekely M, Carletto L, Garami A (2015) The pathophysiology of heat exposure. Temperature 2 (4):452. https://doi.org/10.1080/23328940.2015.1051207

Webber T, Haensier A, Rechid D, Pfeifer S, Eggert B, Jacob D (2018) Analysing regional climate change in Africa in a $1.5,2$ and $3{ }^{\circ} \mathrm{C}$ global warming world. Earth's Future 6:643-655. https://doi.org/10.1002/2017EF000714

White-Newsome JL, Sanchez BN, Jolliet O, Zhang Z, Parker EA, Dvonch JT, O’Neil MS (2012) Climate change and health: indoor heat exposure in vulnerable populations. Environ Res 112:20-27. https://doi.org/10.1016/j.envres.2011.10.008

Wittenberg M, Collinson M (2017) Household formation and household size in post-apartheid South Africa: evidence from the Agincourt sub-district 1992-2012. Demogr Res 37:Article 39, 1297-1326. https://doi.org/10.4054/DemRes.2017.37.39

Wright CY, Street RA, Cele N, Kunene Z, Balakrishna Y, Albers PN, Mathee A (2017) Indoor temperatures in patient waiting rooms in eight rural primary health care centres in Northern South Africa and the related potential risk to human health and wellbeing. Int J Environ Res Public Health 14(1):43. https://doi.org/10.3390/ijerph14010043

Yohanis Y, Mondol D (2010) Annual variations of temperature in a sample of UK dwellings. Appl Energy 87:681-690. https://doi.org/10.1016/j.apenergy.2009.08.003. (2009)

Open Access This chapter is licensed under the terms of the Creative Commons Attribution 4.0 International License (http://creativecommons.org/licenses/by/4.0/), which permits use, sharing, adaptation, distribution and reproduction in any medium or format, as long as you give appropriate credit to the original author(s) and the source, provide a link to the Creative Commons license and indicate if changes were made.

The images or other third party material in this chapter are included in the chapter's Creative Commons license, unless indicated otherwise in a credit line to the material. If material is not included in the chapter's Creative Commons license and your intended use is not permitted by statutory regulation or exceeds the permitted use, you will need to obtain permission directly from the copyright holder.

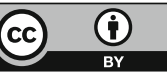

